\title{
REORGANIZACJA PARLAMENTARYZMU GRECKIEGO PO 1911 ROKU
}

\section{THE REORGANIZATION OF THE GREEK PARLIAMENTARISM AFTER 1911}

Greece's defeat in the war with Turkey in 1897 resulted in submitting the state's finances to the control by an international committee and provoked the necessity to introduce systemic reforms. The role of the father of modernization was vested in the new Prime Minister, Alexandros Zaimis, who on 29 October 1898 submitted to King George an extensive memorandum specifying the directions of essential reforms, indispensable to stabilize the country's situation. The main goal was to "rebuild the state and the country", and the means to achieve it was a fundamental modernization in such spheres as organization of the state, administration of justice, fiscal system, as well as education and social welfare. The main achievement of the modernization policy was the passing of the Constitution (27 May 1911), amending the fundamental law of 1864. The Constitution mainly improved the lawmaking process and until Greece joined the Second World War, it had been the basic point of reference in systemic issues.

Słowa kluczowe: administracja, reformy, konstytucja, ustrój, system polityczny

Key words: administration, reforms, constitution, system, political system

* Prof. Spyridon G. Ploumidis, National and Kapodistrian University of Athens, sploumid@arch.uoa.gr, https://orcid.org/0000-0002-7243-2844

\section{KLESKA W 1897 ROKU JAKO DOŚWIADCZENIE}

T pokarzająca porażka Grecji w wojnie z Turcją w 1897 r. i ograniczenie suwerenności państwowej w wydatkach nałożone w 1898 r. przez międzynarodową kontrolę finansową stały katalizatorami dla późniejszych wydarzeń politycznych w kraju. Te dwa wydarzenia sprawiły, że wśród polityków sprawujących władzę i opozycji potrzeba reformy państwa i uzdrowienia życia publicznego nie budziła żadnych wątpliwości ${ }^{1}$. Wybitny historyk i publicysta Trifon Evagelidis (1863-1941), konstatując „kryzys”, jaki przechodził kraj, życzył, aby po podpisaniu ostatecznego układu pokojowego z Turcją ,nadeszło oczyszczenie politycznego i wojskowego pola z ostów i cierni” i przede wszystkim, aby ,zostało odnalezione źródło politycznego i społecznego marazmu Grecji we wszystkich gałęziach administracji i żeby wyrwała się ona z jego objęcia"2. Kierunek nowej epoce wyznaczył Aleksandros Zaimis, który objął urząd premiera po ustępującym Dimitriosie Rali i w parlamentarnym przemówieniu 21 września 1897 r. zapowiedział reformy. Podkreślił też „obowiązek” wszystkich politycznych liderów kraju zadbania „w jedności” o wprowadzenie „radykalnych reform w administracji kraju i przy podejmowaniu środków służących reorganizacji wojska

${ }^{1}$ N. Maroniti, Wtadza polityczna i ,kwestia narodowa” w Grecji, 1880-1910, Ateny 2009, s. 211, 240.

2 T.E. Evangelidis, Wojna grecko-turecka (6 kwietnia-7 maja 1897) z wprowadzeniem do kampanii kreteńskiej (2 lutego-14 maja), Ateny 1897, s. 871; T. Evangelidis zakończył pisanie swego dzieła 30 maja $1897 \mathrm{r}$. 
i marynarki wojennej”, które ocaliłyby Grecję z dotykającej ją „katastrofy”3. Zaimis przedłożył 29 października 1898 r. królowi Jerzemu obszerne memorandum prezentujące reformy, których potrzebował kraj i do których przeprowadzenia zostałby wezwany następny rząd wyłoniony w drodze wyborów. W swym wystąpieniu Zajmis zaznaczył potrzebę wprowadzenia zmian we wszystkich dziedzinach życia publicznego: administracji, wymiarze sprawiedliwości, bezpieczeństwie, finansach, edukacji, instytucjach kontroli państwowej, polityce zagranicznej, wojsku i marynarce, policji, prasie oraz zaproponował środki „użyteczne i celowe, prowadzące do modernizacji kraju”. Jako główny powód zapaści kraju wskazał tzw. „wymianę przysług”, tj. klientelistyczny sposób funkcjonowania systemu politycznego ${ }^{4}$. Premier zakończył memorandum w następujący sposób: „Mam nadzieję, że grecko-turecka wojna będzie miała ten przynajmniej pożytek, że uczyni nas bardziej rozumnymi i że gorzkie doświadczenia dostarczą nam sił, byśmy uwolnili się od tych zjawisk, które istniejąc od dawna, stały się doskonałą pożywką nieszczęść, jakie spotkały ojczyznę"”.

Polityczna dyskusja o reformach uległa intensyfikacji przed zbliżającymi się wyborami parlamentarnymi, rozpisanymi na 7 lutego 1899 r. Sloganem najczęściej towarzyszącym wypowiedziom pojawiającym się w kampanii wyborczej było słowo „reforma”. Wyborcy epatowani byli negatywnym wizerunkiem kandydatów Partii Narodowej (Teodora Dilianiego), wskazywanymi jako główni winowajcy upokorzenia, jednocześnie zaś zachęcani do aprobaty stronnictw eksponujących potrzebę reformy i zmiany ${ }^{6}$. Atmosfera niezadowolenia była wszechobecna, a powszechne poczucie krzywdy kładło się cieniem na całej kampanii. Pewien profesor filozofii i prawa na Uniwersytecie Narodowym przedstawił „czarny” obraz całej sytuacji, jednak pozostawiając cień nadziei: „Nikt w kraju nie uważa, żebyśmy posiadali sprawny wymiar sprawiedliwości, porządną edukację, administrację użyteczną i bezstronną, system podatkowy znośny, wojsko i marynarkę godną swoich celów. Wszystko jest zgniłe, wszędzie panuje nędza. Naród jest chory, cierpi na chorobę ledwie poddającą się terapii, ale na szczęście nie całkiem nieuleczalną"7.

Tworem wymagającym uzdrowienia było oczywiście państwo ${ }^{8}$. Wspomniany autor na łamach prasy stwierdził, że u podstaw zła leżała polityczna korupcja i w związku z tym ocalenie kraju zależało od wymiany elit, dokonanej za pomocą wyborów do ciała wyborczego: „«Naród» powinien wybrać reformatorskie twarze, które wprowadziłyby konieczne polityczne reformy"9. Głównym orędownikiem i motorem zmian stała się

3 N. Maroniti, op. cit., s. 219-220.

4 A.T.A. Zaimis, Memorandum do Jego Królewskiej Mości, [w:] Dzienniki Rządowe, t. 1, nr 190 (18 listopada 1898), s. 525-530.

5 N. Maroniti, op. cit., s. 238.

${ }^{6}$ N. Maroniti, Sity polityczne w pierwszej dekadzie XX wieku, [w:] Zamach w Gudi w roku 1909, red. N. Maroniti, Ateny 2010, s. 21-23.

7 D.S. Zalouhos, Co powinna zrobić Grecja, aby uniknać upadku?, Ateny 1898, s. 3-5. Broszura została przygotowana w maju w ramach przygotowań do wyborów krajowych.

8 Ibidem, s. 3.

9 Ibidem, s. 4-6, 14. 
Nowotrikupicka Partia Modernistyczna ${ }^{10}$, której liderem w listopadzie 1898 r. został Jerzy Theotokis. Zasadniczym twórcą programu wyborczego Partii Modernistycznej, opublikowanym pod tytułem „Reforma i Odnowa”, był działacz polityczny i autorytet w kwestii finansów publicznych Athanasios Eftaksias (były minister ds. wyznań i oświecenia publicznego) ${ }^{11}$. Należy zaznaczyć, że już następnego dnia po ogłoszeniu klęski w wojnie z Turcją Eftaksias wyraził publicznie, na łamach periodyka „Neolog z Konstantynopola” swoją opinię, że „sprawy państwa greckiego idą w złym kierunku”, oraz że „istnieje coś zmurszałego w niej samej [Grecji] i dąży ona do całkowitej katastrofy". Zdaniem Eftaksiasa istniała pilna potrzeba żeby rządzący oddali się ,jak najszybciej dziełu odnowy” poprzez wdrożenie radykalnych reform. Od „odnowy wszystkiego” miało zależeć „ocalenie ojczyzny”. „Reformy ustrojowe, na podstawie których mógłby funkcjonować właściwy i nienaruszany nasz ustrój i ukształtowałaby się stabilna rzeczywistość", miały spowodować odnowę wszelkich dziedzin życia publicznego, finansów, administracji i sądownictwa, edukacji i kościoła, sił zbrojnych i infrastruktury kraju. Grecja znajdowała się „na granicy życia i śmierci”, co było wynikiem utrzymywania „klientelistycznego systemu”, uznanego za „źródło zła”. Nieszczęście narodu miało wynikać z istnienia ,jednej izby przedstawicieli narodu”. Dlatego proponował ustanowienie „górnej izby lub senatu”, które hamowałaby „wieczne aberracje i nadużycia tych z góry i tych z dołu". Istniała zatem natychmiastowa potrzeba powołania dodatkowej „izby rewizji”, niezbędnej dla zagwarantowania właściwego wprowadzenia ustawowych ,potrzebnych reform ustrojowych”. W ramach konstytucyjnej rewizji Eftaksias zaproponował ograniczenie prawa wyborczego i wykluczenie z list wyborczych ,przynajmniej tych, którzy nie umieli pisać i czytać” oraz ustanowienie świadectwa ukończenia szkoły podstawowej jako kryterium uzyskania praw wyborcy. Równocześnie wskazał na konieczność ustanowienia „publicznych egzaminów praktycznych” jako podstawy do (nawet tymczasowego) zatrudnienia bądź awansu urzędnika publicznego wszystkich szczebli ${ }^{12}$.

W grudniu 1898 r. Eftaksias zaostrzył retorykę w kwestii oceny położenia Grecji. Jego zdaniem, wśród powodów, które sprawiały, że reformy ustawodawcze stawały się koniecznymi i pilnymi, znajdowały się bankructwo państwa, wojna z $1897 \mathrm{r}$. oraz chaos, spowodowały w kraju przed rywalizację polityczną, która miała dojść do „skrajnie ostrego stadium”. Były minister Charilaos Trikupis naszkicował sytuację w czarnych barwach: „Nic nie jest na swoim miejscu w Grecji, ani finanse, ani kościół i wychowanie, ani administracja i sądownictwo, ani wojsko i marynarka, ani nasza służba zagraniczna". Wskazywał, że reforma oraz odnowa muszą mieć charakter całościowy, a kwestia reformy ciał ustawodawczych ma pilny charakter. Od niej bowiem

${ }^{10}$ Nazwa pochodzi od nazwiska Charilaosa Trikupisa, greckiego polityka, siedmiokrotnego premiera Grecji w latach 1875-1895 [przyp. thum.].

${ }^{11}$ N. Maroniti, Władza polityczna..., s. 254-256; idem, Sity polityczne w pierwszej dekadzie XX wieku..., s. 23 (przyp. 3).

12 A.P. Eftaksias, Grecja na granicy życia i śmierci. Studium polityczne przedrukowane z Neologa z Konstantynopola, Ateny 1897, s. 3-7, 12, 17, 21, 31-32, 46, 59, 99, 125, 173-174. 
miało zależeć „ocalenie ojczyzny”13. Jako kolejny obszar wymagający naprawy wskazywał kwestie gospodarcze i usprawnienie administracji. W praktyce oznaczało to, że urzędnicy państwowi zostaliby ograniczeni do „absolutnie niezbędnych”, a ze służby publicznej zostałby wydalony „,cały nadliczbowy i zbędny personel”. Dokładnie z tego powodu A. Eftaksias (który w 1909 r. został wyznaczony na ministra finansów w rządzie Kiriakuli Mawromichali) był przeciwny stałemu umocowaniu urzędników. Jawił się natomiast jako zwolennik „bezprecedensowego oczyszczenia różnych obszarów z każdego nieumiejętnego i niepotrzebnego urzędnika bez prawdziwych kwalifikacji” i rozpoczęcia ,administracyjnej odnowy kraju”, polegającej na łączeniu prowincji i ustanowieniu zasady samowystarczalności gmin i wspólnot. Wśród reform ekonomicznych zwracało uwagę podniesienie wieku emerytalnego oraz ograniczenie robót publicznych, a tzw. polityka „radykalnych finansów” miała prowadzić równocześnie do zmniejszenia obciążeń podatkowych i przynieść ulgę od „podatkowego wycieńczenia” pewnym klasom. Jego zdaniem, część społeczeństwa niesłusznie i w nieproporcjonalny sposób była uciskana przez podatki pośrednie i przestarzałe obciążenia bezpośrednie (tak jak np. podatek hodowlany). Na program modernizacji złożyły się również reforma taryf celnych, zwiększenie opłat za dobra luksusowe oraz zmniejszenie nadmiernego opodatkowania „wielu przedmiotów powszechnej konsumpcji”" ${ }^{14}$. Podkreślona została również potrzeba rozbudowy infrastruktury komunikacyjnej (drogowej, morskiej i kolejowej), wzmocnienie publicznego porządku i bezpieczeństwa, reformy wymiaru sprawiedliwości, zreformowania od fundamentów prawodawstwa regulującego działalność instytucji kredytowych i przedsiębiorstw. Eftaksias forsował również pomysł inicjatywy państwa w tworzeniu nowych instytucji bankowych, kredytujących produkcję rolną. Polityka rolna powinna służyć osiągnięciu przez państwo samowystarczalności w kwestii produktów żywnościowych. Kolejnym krokiem służącym osiągnięciu tego celu miała stanowić reforma rolna i przydział ziemi bezrolnym mieszkańcom wsi. Równą troskę należało wykazać wobec rolniczej edukacji: w każdej gminie powinny zostać stworzone szkoły rolnicze. Zainteresowanie rządu powinno również zwrócić się w stronę przemysłu, handlu i transportu wodnego, z ostatecznym celem, aby „uczynić z Grecji najbogatsze i najsilniejsze pod względem ekonomicznym państwo Wschodu" 15 .

Innymi elementami programu odnowy partii Nowotrikupickiej była reforma edukacji określona mianem „kamienia milowego wszelkiej innej reformy w Grecji”, która sama w sobie powinna być „radykalna i ukierunkowana na wszystkie gałęzie edukacji”. Podkreślano przy tej okazji potrzebę upowszechnienia praktycznej i „rzeczywistej” edukacji średniej (handlowej, przemysłowej i zawodowej) i włączenia kobiet w system edukacji. Kodyfikacja prawa cywilnego stanowiła również jedną z wymaganych rzeczy, tak jak poprawa jakości funkcjonowania służby dyplomatycznej. Jednak za najbardziej żywotną została uznana kwestia „reorganizacji i ponownego uformowania wojska”, tak

\footnotetext{
13 A.P. Eftaksias, Reforma i rehabilitacja, Ateny 1899, s. 3-9.

${ }^{14}$ Ibidem, s. 1-6, 64, 66, 68.

${ }^{15}$ Ibidem, s. 15-17, 19-22, 24-25.
} 
aby nie powtórzył się „koszmar roku 1897”. Tylko w ten sposób Grecja była w stanie podnieść się po „,stanie upadku”, w którym się wówczas znajdowała ${ }^{16}$.

Eftaksias i Partia Modernistyczna Theotoka nie byli jedynymi zwolennikami reform i odnowy. Podobne programy w przededniu wyborów stworzyli i przedstawili Konstantinos Karapanos ${ }^{17}$ oraz Stephanos Dragumis ${ }^{18}$. Nawet pogrążona w kryzysie Partia Narodowa uznała potrzebę wyznaczenia głównych kierunków polityki finansowej, ograniczenia publicznych wydatków, zmniejszenia opodatkowania i zagranicznych kredytów $^{19}$. Dragumis w wielu wypowiedziach dla prasy (m.in. 17 lipca i 15 sierpnia 1897 r.), domagał się ,uleczenia spraw, które źle się w państwie mają” i połączenia reform z „metodycznym przekształceniem” konstytucji. Obowiązkiem polityków jego zdaniem - miała być „odnowa ogólnych spraw publicznych”, skupiona na trzech kierunkach: administracyjnym, wojskowym i sądowym. Jednak przemiana ta powinna dokonać się bezwzględnie ,wewnątrz granic ustroju konstytucyjnego”. Innymi słowy, reforma, choć powinna być „szczera i odważna”, w żadnym wypadku nie mogła dotykać fundamentów konstytucji z 1864 r., a przede wszystkim formy ustroju oraz pozycji króla $^{20}$. Karapanos posługując się podobną argumentacją opowiedział się za radykalnymi reformami w obszarach administracji, sądownictwa, edukacji, strukturze duchowieństwa, służby zagranicznej, wojskowości i ustroju finansów (głównie za zmniejszeniem i reformą podatków). Głównym punktem „,koniecznych środków ku odnowie państwa” była ,poprawa różnych gałęzi szeroko pojętej administracji”, publicznych służb administracyjnych i sądownictwa. Jako źródło zła wskazana została ,partiokracja” i niedostateczne zainteresowanie polityków interesem ogółu. Prezes partii postępowej okazał się w swoim programie odnowy bardziej konserwatywny od Dragumisa i popierał utrzymanie dotychczasowego kształtu Zgromadzenia Narodowego ${ }^{21}$. Niemniej za główną przyczynę i źródło „nieszczęścia” kraju zostało wskazane zjawisko tzw. wymiany przysług, prowadzące do zamknięcia klasy politycznej oraz ,złe zarządzanie”22. Diagnoza ta zyskała potwierdzenie w stanowisku króla Jerzego Pierwszego, który w swojej mowie tronowej, wygłoszonej podczas inauguracji parlamentu 15. kadencji (4 marca 1899 r.) uznał potrzebę ,poprawy służby publicznej poprzez prawodawstwo”. Poprawę tę zamierzano osiągnąć m.in. poprzez ,założenie Najwyższej Nadzorczej Rady Państwowej”, „organizację regularnej kontroli różnych gałęzi służby publicznej”, „ustalenie zasad przyjęcia do służby publicznej i awansu urzędników”, „reformę sposobu awansów i zmian stanowiska sędziów” oraz ,poprzez zaproszenie specjalistów z zagranicy celem organizacji pełnych gałęzi służby publicznej”. Grecki monarcha w swojej mowie zaznaczył również, że należy koniecznie uformować siły wojenne państwa na lądzie i na

${ }^{16}$ Ibidem, s. 37, 43, 50, 76-78, 86-89, 91-97, 100-101, 104.

${ }_{17}$ K. Karapanos, Stan kraju oraz konieczne środki uzdrowienia, Ateny 1898.

18 S. Dragumis, Ku dziele odnowy. Listy i myśli polityka, byłego posła Megarida, Ateny 1897.

19 A.P. Eftaksias, Reforma i rehabilitacja..., s. 254.

20 S. Dragoumis, Ku dziele odnowy..., s. 6, 10, 51-52, 54.

${ }^{21}$ K. Karapanos, Stan kraju..., s. 6, 8, 11, 16-17, 20, 24-26, 30, 32-33, 47, 49, 58.

22 A.N. Vernardakis, O katastrofie, o niszczącej wojnie oraz o naszym wyjściu z kryzysu, Ateny 1898 , s. $1,122-123$. 
morzu, poprawić finanse państwa, odnowić publiczne i prywatne kredyty, troszczyć się o zdrową sytuację państwa, rozwinąć instytucje prawdziwie samoadministrujące się, jak i również cały szereg ustawodawczych środków „,ku poprawie kościoła i edukacji”, mając za cel rozwój „narodowej produkcji”, „obronę praw pracowników przemysłu, w tym kobiet i dzieci"'23. Mowa króla, m.in. ze względu na zapowiedź uregulowania kwestii prawa pracy, spotkała się z dobrym przyjęciem. Jedynym odstępstwem była wypowiedź T. Dilianisa, który miesiąc po mowie tronowej — wbrew powszechnym nastrojom stwierdził z mównicy sejmowej, że wskazanie „wymiany przysług” jako przyczyny klęski miało charakter ,zwodzenia świadomości publicznej”24.

\section{WENIZELIZM ODNOWY}

W trakcie następnej dekady po nieszczęsnej grecko-tureckiej wojnie, kolejnym rządom Grecji nie udało się odpowiedzieć zadowalająco na ogólną potrzebę reform i odnowy. Celebrowany powrót T. Deligiannisa do władzy ${ }^{25}$ stanowił uderzający dowód restytucji polityki przeszłości. Równocześnie zwolennicy reform politycznych skupieni wokół G. Theotokisa byli zmuszeni przyjąć krytykę za porażkę w sprawach publicznych, przede wszystkim w polityce zagranicznej: rywalizacji z Bułgarią (w kwestii Macedonii) i z Turcją (w sprawie Krety). Klęski Grecji na arenie międzynarodowej ponownie zarówno te w 1897 r., jak i w 1909 r. stały się zapalnikiem i napędem politycznych wydarzeń. Bezczelne i upokarzające względem Grecji groźby oraz rewolucyjny przykład Neoturków były podstawową przyczyną próby zamachu greckich oficerów w Gudi ${ }^{26}$. „Błędna postawa” rządów Rallisa i Theotokisa wobec Wysokiej Porty dosłownie rozwścieczyły prasę i opinię publiczną ${ }^{27}$. Następnego dnia po zamachu w 1909 r. pewien prawnik i dziennikarz, komentując sytuację, miał stwierdzić, że głównym powodem, dla którego wściekła reakcja przeciw Theotokowi była tak szczególnie silna było to, że: „Zarządzając tym krajem przez prawie dziesięć lat po nieszczęsnej wojnie 1897 r. nie zrobił niczego, żeby zmodernizować Grecję, ale przeciwnie, pozostawił ją nagą i nieprzygotowaną na lądzie i na morzu, niezdolną do strzeżenia jej granic, chorą i nie dość silną, aby domagać się sprawiedliwości, w wyniku czego staje się obiektem kpin, upokorzeń, wyzwisk i szyderstw"28.

${ }^{23}$ Dziennik Urzędowy debat parlamentarnych, Biuletyn 15, sesja 1, przewodniczący N. Tsamadou, Ateny 1899, s. 3-4.

${ }^{24}$ Ibidem, s. 61 (posiedzenie z 3 kwietnia 1899 r.).

${ }^{25}$ W wyborach z 20 lutego 1905 r., partia T. Deligiannisa zdobyła 142 spośród 235 miejsc w parlamencie. N. Economou, Wewnętrzne procesy polityczne w okresie 1905-1909. Historia narodu greckiego, Ateny 1977, s. 179-180. T. Pangalos skomentował powrót ,demagoga” Deligiannisa do władzy w następujący sposób: „ów nie do opisania rządca, który doprowadził naród do ostatecznego poniżenia i hańby w roku 1897, został mianowany po niewielu latach na wszechmogącego premiera”. T. Pangalos, Moje wspomnienia 1897-1947. Burzliwy okres ostatnich 50 lat, t. 1, Ateny 1950, s. 30.

26 A.M. Ainian, Wspomnienia, Ateny 1948, s. 90, 93, 96.

27 Vide „Akropolis”, 26 IX 1908, nr 6278, s. 1. „Estia”, 6 VIII 1909, nr 5572, s. 4. Wcześniej przedstawiciele ruchu radykłów G. Filaretosa ocenili, że kryzys w kwestii kreteńskiej „,spowoduje erupcję wulkanu ludności” w Grecji.

${ }^{28}$ C.K. Oikonomou, Myśli na temat sytuacji: co powinno się stać, Ateny 1909, s. 6. 
Równocześnie „cały grecki lud” z cechami rzemieślniczymi w roli głównej, które reprezentowały „,́wiadomość ludową”, „powstały przeciwko obowiązującemu systemowi”, zażądały zmiany spraw i w pierwszej kolejności zmiany systemu sądowniczego, „,miany nie twarzy, ale zmiany systemu, likwidacji wszystkich zbędnych stanowisk, i stosowanie surowej polityki finansowej"22.

W 1909 r. Grecja niezmiennie znajdowała się w ostrym kryzysie „między życiem a śmiercią" i jako powód tego stanu rzeczy była wskazywana „korupcjokracja” i „rozwiązłe zarządzanie”. Ponownie pojawił się postulat odnowy oznaczający „podjęcie zdecydowanych, prawdziwych kroków w stronę ustanowienia gotowego do walki narodowego wojska oraz silnej floty z takim skutkiem, aby wywalczyła niezbywalne prawa greckiego narodu" ${ }^{\prime 30}$. Na celowniku prasy, która odegrała rolę katalizatora w politycznych wydarzeniach 1909 r., znalazła się jeszcze raz administracja, a jako jeden z głównych postulatów zostało wysunięte hasło modernizacji systemu parlamentarnego. Ton „powstania” nadała „Akropolis”31. Na jej łamach Wlasis Gawrilidis określił system parlamentarny i partie jako „tyranów ludu”32 i źródło wszelkiego zła: „Partie, które zajęły sądownictwo, wstrząsnęły bezpieczeństwem, oddały państwo w ręce sofistów i nieuków, przeszkadzają w logicznym rozwoju kraju, ograniczają wiarę, ograniczają kapitał, ograniczają pracę, popychają do emigracji, palą lasy, pozostawiają rzeki bez mostów, napełniają kraj złoczyństwem, zniechęcają do zakładania przedsiębiorstw, tworzą dług, kładą na kolana rolnictwo i powielają biedę" "33.

Wlasis Gawrilidis doszedł do wniosku, że „nasz parlamentaryzm ze swoimi przestarzałymi metodami uległ zepsuciu do tego stopnia, że sam wie, że jest anachronizmem”. Biorąc ten stan pod uwagę, określił ustrój państwa mianem martwego, znajdującego się w stanie rozkładu ${ }^{34}$. W swojej diagnozie podkreślił również, że za „straszliwe opłaty” i nadmierne obciążenie podatkowe odpowiedzialna była ,pięćdziesięcioletnia parlamentarna grabież" kraju, która doprowadziła wszystkie klasy społeczne, bez wyjątku, do całkowitej ekonomicznej katastrofy i politycznie popchnęła je w objęcia socjalizmu. Nadziei upatrywał jedynie we wspólnym działaniu króla, parlamentu i rządu podjętym, aby „odwrócić nadchodzącą katastrofę" ${ }^{35}$. Odpowiedzialność za całe „,narodowe nieszczęście” została zrzucona na zepsutych „zawodowych polityków”, partie polityczne, doprowadziły naród do biedy i zadłużenia, oraz parlamentaryzm, ten „brudny ustrój”,

29 Ibidem, s. 8, 48.

30 Ibidem, s. 10, 54.

31 Czołowa gazeta epoki fin de siècle o największym nakładzie, wyróżniająca się radykalnym tonem i wpływem na nastroje społeczne. N. Oikonomou, op. cit., s. 191; V. Papakosmas, Armia w życiu politycznym Grecji. Zamach stanu z 1909 r. i jego wpływ do chwili obecnej, Ateny 1981, s. 70; O. Polykandriotis, Akropolis, [w:] Encyklopedia greckiej prasy 1784-1974. Gazety, czasopisma, dziennikarze, red. L. Droulia i Y. Koutsopanagou, t. 1, Ateny 2008, s. 159; L. Tricha, Gavrielidis, Vlassis, [w:] Encyklopedia greckiej..., s. 407-408.

32 „Akropolis”, 13 II 1909, nr 6409, s. 1.

33 „Akropolis”, 11 IX 1909, nr 6617, s. 1.

34 „Akropolis”, 31 I 1909, nr 6398, s. 1.

35 „Akropolis”, 3 II 1909, nr 6401, s. 1. 
który ,jak wąż udusił naród”36. Wskazywał na potrzebę zastosowania „drastycznych i radykalnych [prawodawczych] środków”, które oddaliłyby niebezpieczeństwa wewnętrzne i zewnętrzne ${ }^{37}$.

Wściekłość i krytyka spływająca z łamów „Akropolis”, skierowana przeciwko partiom zwielokrotniała się pod wpływem niezdolności ,zadłużonego państwa greckiego” do ochrony ,homogenicznych Greków” przeciwko prześladowaniom ze strony Turków i Turkoalbańczyków ${ }^{38}$. Grecy potrzebowali zatem nowych polityków, którzy położyliby kres „,sromocie”39. 22 maja 1909 r. tekst Gawrilidisa ogłosił „dziennikarską kampanię" w imię rozgłoszenia idei pokojowej rewolucji, która ocaliłaby ostatecznie Grecję ${ }^{40}$. Pokojowa rewolucja miała obalić „rządzącą, zepsutą oligarchię”, która była obojętna wobec narodowych interesów ${ }^{41}$. Jądro rewolucji miał stanowić „ruch cechów”, który reprezentowałby warstwy ludowe, a główną metodą osiągnięcia celu miały być protesty ${ }^{42}$.

Żądanie „odnowy” i „uwolnienia państwa z niespotykanej korupcjokracji w masce konstytucyjności i parlamentaryzmu” znajdowało swoje odbicie w publicystyce organu prasowego wojska, tj. tygodnika „Czas”. Na jego łamach m.in. Kostia Cheropulu oceniał, że Grecja pozostawała w niebezpieczeństwie „pogrzebania pod ruinami korupcjokracji”, czyli „wymiany przysług, sympatii, układów”43. „Korupcjokracja” i ,posłokracja” miały zanieczyszczać państwo i naród, co prowadziło do wniosku, że kraj potrzebował politycznego przewrotu ${ }^{44}$. Państwo chyliło się ,ku szlamie kłamstwa i nieetyki, ku błotu bezprawia i szarlatanerii”, w związku z czym Grecy byli zobowiązani do podjęcia ,rezurekcji”, żeby przywrócić ,„państwo i jego władców i rządzących na drogę ku sprawiedliwości i prawdzie"45. Równocześnie z postulatami reform politycznych domagano się odnowy polityki fiskalnej ${ }^{46}$, ocenianej jako bezpośrednia konsekwencja skorumpowanego systemu politycznego. Ateńskie cechy w swojej petycji skierowanej do króla (18 lutego 1909 r.) skarżyły się, że obowiązująca wymiana przysług i złe zarządzanie zrodziły „manię podatkową”, tj. nadmierne, ,ciężkie i niesprawiedliwie naliczone podatki”, które miały utrzymać płace bez pracy oraz klientów arywistów i partii osobistych ${ }^{47}$. W odniesieniu do Zgromadzenia Narodowego padły też konkretne zarzuty: „W kraju podziałów osobistych i osobistych korzyści, instytucje parlamentarne

36 „Akropolis”, 12 II 1909, nr 6408, s. 1; „Akropolis”, 14 II 1909, nr 6410, s. 1.

37 „Akropolis”, 12 II 1909, nr 6408, s. 1.

38 „Akropolis”, 14 II 1909, nr 6410, s. 1.

39 „Akropolis”, 31 III 1909, nr 6454, s. 1.

40 „Akropolis”, 22 V 1909, nr 6506, s. 1.

41 „Akropolis”, 28 V 1909, nr 6512, s. 1.

42 „Akropolis”, 29 VI 1909, nr 6543, s. 1.

43 „Czas”, 13 XII 1909nr 2239, s. 1; „Czas”, 23 VI 1909, nr 2065, s. 1.

44 „Czas”, 13 IX 1909, nr 2146, s. 1.

45 „Czas”, 29 III 1909, nr 1990, s. 1.

46 G.B. Dertilis, Historia państwa greckiego 1830-1920, t. 2, Ateny 2006, s. 735-736, 756.

47 S.G. Ploumidis, Zamach z 1909 r. Zbiorowe przedmioty i fakty, [w:] Zamach 1909, red. V. Maronitis, Ateny 2010, s. 62-63. 
okazały się plugawymi organami korupcji, przestępczości, anarchii bezprawia, katastrof ekonomicznych i politycznych dramatów"48

W prasie coraz częściej pojawiały się spektakularne obrazy agonii systemu i stwierdzenia, że „nigdzie nie widać wyjścia” od istniejącego systemu rządowego i od „rozpaczliwej sytuacji wszystkich gałęzi administracji" ${ }^{49}$. Niemniej starano się wymusić stan, w którym „leczenie niedoskonałości ustroju” dokonywało się nie na drodze radykalnego przewrotu, ale przez pokojową reformę ustroju przeprowadzanego przez ciała ustawodawcze w określonej procedurze, „bez szkodliwych wstrząsów wewnętrznych” lub „bezprawnych, antyparlamentarnych szantaży”50.

Rozwiązanie takiej sytuacji bez wyjścia przyniosła ostatecznie pokojowa „rewolucja" (tzn. społeczny i przede wszystkim wojskowy ruch) w $1909 \mathrm{r}$. Ten pokojowy protest, w którym role odegrały cechy rzemieślnicze z Aten i Pireusu, stanowił przełom w historii greckiego państwa. Wówczas bowiem niemal cały lud grecki i w stolicy i na prowincji zażądał koherentnego i godnego rozwiązania wielu poważnych i ciągnących się problemów życia publicznego. Grecy zjednoczeni i zorganizowani opowiedzieli się za określonym programem reform, które zlikwidowałyby „wymianę przysług" i stanowiłyby o cywilnej modernizacji kraju. Obszerny opis wspólnych żądań został sformułowany w petycji Wojskowej Unii do rządu D. Ralli i w głosowaniu na zgromadzeniu 14 września na Pedion tou Ares [ateńskie Pole Marsowe]. Jednak najważniejsze i decydujące wydarzenie rewolucji było zaproszenie Eleftheriosa Venizelosa do Aten i powierzenie mu władzy (15 sierpnia 1909 r.). Reformy (z główną, jaką była rewizją konstytucji w 1911 r.) i zmiany w strukturze państwa, które przeprowadziły kolejne rządy E. Venizelosa, w finansach, w relacjach zawodowych, w rolnictwie, w edukacji i w wielu innych zasadniczych dziedzinach, stanowiły w gruncie rzeczy prawdziwą rewolucję ${ }^{51}$. Wraz z ruchem w 1909 r. rozpoczął się 10-letni

48 „Epoki”, 16 II 1909, nr 45, s. 1.

49 „Epoki”, 18 II 1909, nr 47, s. 1.

50 Jak wskazywano: „cierpiący naród i męczący się w złym zarządzaniu, łaknie politycznych reform władzy ustawodawczej i konstytucyjnej względem Zgromadzenia Narodowego, pragnie pokojowej reformy systemu państwowego”. „Epoki”, 19 II 1909, nr 48, s. 1.

51 Odnośnie zamachu z 1909 r. i jego średnioterminowych pozytywnych efektów, orientacyjnie: T. Veremis, Zamach wojskowy z roku 1909, [w:] Historia narodu greckiego, t. 14, Ateny 1977, s. 258-266; idem, Zamach z Gudi otwiera droge Venizelosowi, [w:] Eleftherios Venizelos, red. T. Veremis, E. Nikolakopoulos i V. Panagiotopoulos, t. 1 (Od okupowanej przez Turcje Krety do podziatu Narodu), Ateny 2011, s. 93-98; G.B. Dertilis, Transformacja społeczna i interwencja wojskowa 1880-1909, Ateny 1977, s. 172-175; G. Hering, Partie polityczne w Grecji 1821-1936, thum. Thodoros Paraskevopoulos, t. 2, Ateny 2008, s. 749-776; N.K. Alivazatos, Venizelos i instytucjonalna modernizacja kraju, [w:] Eleftherios Venizelos..., s. 99-117; idem, Konstytucja i jej wrogowie w nowożytnej greckiej historii, 1800-2010, Ateny 2011, s. 156-158; S. Ploumidis, ibidem, s. 61-80; N. Maroniti, Zamach z Gudi sto lat później: Założenia, pytania, nowe perspektywy, Ateny 2010, s. 176-186, gdzie analizowane są perspektywy badań historycznych. T. Papkos, Polityka wydatków publicznych, [w:] Historia gospodarcza państwa greckiego, red. T. Kalafatis i E. Prontas, konsultant redakcyjny S. Asdrakhas, t. 2 (Funkcje gospodarcze i wydajność), Ateny 2011, s. 371-374; K. Svolopoulos, Uwagi na temat Eleftheriosa Venizelosa, Ateny 2014, s. 29-40; G.Th. Mavrogordatos, 1915. O podziat Narodu, Ateny 2015, s. 21-29. 
twórczy okres (1910-1920), który Thanasis Diamantopulos określił mianem „Wenizelizm odnowy" 52 .

Thanasis Diamantopulos zaproponował swoje pomysły i idee liberalne oraz ,innowacyjne dzieło" Venizelosa w systemie politycznym. Objęło ono przede wszystkim poprawę działania wymiaru sprawiedliwości i skupiło się na reformie administracji publicznej. Instytucje państwa miały stać się bardziej obiektywne i przejrzyste dzięki odrzuceniu dominacji liderów partyjnych oraz eliminację przeszkód na drodze konsolidacji i egalitaryzmu ${ }^{53}$. Odrodzenie wenizeliańskie miało oznaczać także coś innego: odnowienie od korzeni społeczeństwa obywatelskiego w wyniku upadku partii opartych na autorytetach osobowości i stworzeniu ugrupowań opierających swoje działania na woli kolegialnych organów (Partia Liberalna) ${ }^{54}$. Decydującą rolę w tej „przemianie” - i w dialektycznej relacji związanej z zmieniającą się wciąż polityczną rzeczywistością - odegrała charyzmatyczna osobowość kreteńskiego przywódcy. Jak to skomentowała prasa i polityczni obserwatorzy z epoki, naród grecki rozpoznawał w osobie Venizelosa przyszłego wielkiego polityka Grecji oraz jedyny umysł, który mógł „uratować Grecję" ${ }^{55}$. Venizelos został wybrany w wyborach 8 sierpnia i 28 listopada 1910 r. jako ,długo oczekiwany Mesjasz" ${ }^{56}$, „wielki zbawiciel narodu” ${ }^{57}$, „obiecany przez Boską opatrzność, jako właściwy do ratowania ludu Izraela" ${ }^{\text {}}$. Venizelos stał się ucieleśnieniem odrodzenia, które to stało się następnie główny hasłem politycznym Partii Liberalnej ${ }^{59}$.

\section{ZMIANA KONSTYTUCJI W ROKU 1911}

Pierwszym sukcesem rządu Venizelosa, który wyłonił się po drugiej turze wyborów w listopadzie 1910 r., było przyjęcie nowej konstytucji 27 maja 1911 r. Rząd przedstawił parlamentowi 26 stycznia 1911 r. projekt obejmujący zmienione przepisy, które nie dotykały podstawowych przepisów konstytucji (pozostawiając niezmienionym ustrój, wyznanie itp.). Venizelos poparł umiarkowane zmiany aktów prawnych regulujących funk-

${ }^{52}$ T. Diamantopoulos, Sity polityczne okresu venizelowego, wydanie A (Venizelizm wyciagnięcia z recesji), Ateny 1985, s. 35.

53 „Empros” (Do przodu), 3 III 1912, nr 5519, s. 3 (przedwyborcze wystąpienia Venizelosa w miejscowościach Amaliada i Pyrgos); „Empros”, 4 III 1912, nr 5520, s. 3-4 (przemówienie w Kalamata) i z 7 III 1912, nr 5523, s. 3 (przemówienie w Lixouri). Niezawisłość wymiaru sprawiedliwości została określona dokładniej w ustawie dotyczącej mianowania, przynależności i awansu sędziów i urzędników Najwyższej Rady Sądownictwa i wraz z wprowadzeniem kadencji dożywotniej prokuratorów w konstytucji z $1911 \mathrm{r}$.

54 Vide „Neon Asty” (Nowy Stróż), 21 II 1909, nr 2594, s. 1; „Neon Asty”, 18 IX 1909, nr 2801, s. 1.

55 A.N. Kyriakos, Nowa Ellada: Wielka patriotyczna historia od roku 1897 roku do dnia dzisiejszego i obejmująca przebieg wydarzeń rewolucyjnych z 15 sierpnia 1909, Ateny 1910, s. 430-431.

56 „Empros”, 6 IX 1910, nr 4982, s. 1; „Empros”, 28 XI 1910, nr 5065, s. 1. Vide również „Empros”, 21 XI 1910, nr 5058, s. 1; M. Mazower, The Messiah and the Bourgeoisie. Venizelos and Politics in Greece, 1909-1912, ,The Historical Journal” 1992, nr 35/4 s. 896.

57 „Empros”, 2 VIII 1910, nr 4948, s. 3.

58 „Empros”, 29 XI 1910, nr 5066, s. 1.

59 T. Diamantopoulos, 10 dekad i jeszcze jedna dekada podziałów politycznych: spory polityczne w Grecji w okresie 1910-2017 r., t. 1 (Dekada 1910 — Podział Narodu), Saloniki 2017, s. 33. 
cjonowanie parlamentu na Zgromadzeniu Ogólnym 5 września 1910 r. Zmieniono lub uzupełniono łącznie 54 z 110 artykułów konstytucji z 1864 r. Konstytucja z 1911 r. chroniła i rozwijała zasady liberalne demokracji parlamentarnej i praworządności, zapewniała sprawne funkcjonowanie administracji rządowej. Zagwarantowanie wolności osobistych (równość podatkowa, prawo do bycia członkiem stowarzyszenia i prawo do schronienia), prawo do własności i wolność prasy, dostarczanie zwiększonej gwarancji prawnej przeciwko arbitralnym decyzjom rządu. Zmiana art. 17 konstytucji utorowała drogę do wywłaszczenia tsyflików ${ }^{60}$. Ustanowiono powszechny obowiązek nauki i dostępu do publicznej edukacji na poziomie podstawowym. Przyjęto przepis o ochronie stanowisk i równości urzędników służby cywilnej. Przywrócono Radę Państwa i wyposażono ją w atrybuty naczelnego sądu administracyjnego. Odsunięto wojskowych od czynnej działalności politycznej. Zabroniono posłom do parlamentu pełnienia roli rzeczników osób prywatnych, a także pozostawania w czynnej służbie wojskowej. Nawet zamysł kandydowania miał wiązać się z rezygnacją z czynnej służby wojskowej. Ponadto kontrolę nad przebiegiem wyborów parlamentarnych powierzono nie członkom parlamentu, ale specjalnie utworzonemu w tym celu sądowi (sąd wyborczy). W nowej konstytucji przewidziano uproszczenie procesu legislacyjnego, ograniczenie możliwości obstrukcji, jak również uproszczenie postępowania rewizyjnego. Wprowadzona została systemowa ochrona niezawisłości sędziowskiej, ustanowiono zasadę nieusuwalności prokuratorów, zastępców prokuratorów i sędziów niższej rangi. Jednak wprowadzono ponownie instytucję stanu wyjątkowego (z zawieszeniem indywidualnych swobód) w przypadku zaistnienia zagrożeń zewnętrznych (wojny, powszechnej mobilizacji). Ustanowiono również język katharevousa ${ }^{61}$ językiem urzędowym. Z wyjątkiem dwóch modyfikacji reforma konstytucji z 1911 r. pozostawała zgodna $\mathrm{z}$ duchem liberalizmu oraz regułami demokracji. $\mathrm{Z}$ odnowionej konstytucji wyłoniły się postulaty ruchu socjalistyczno-wojskowego z 1909 r. Z nich wywiedzione zostały w greckim społeczeństwie zasady państwa prawa i panowania ducha praworządności, bezpieczeństwa i sprawiedliwości, w których ,układy nieformalne” (klientelizm) oraz różnorodność praktyk pozainstytucjonalnych występujących w sferze politycznej, ale również administracyjnej, sądowniczej, gospodarczej itp. nie wypaczały ducha praworządności. Wszystko to zostało zapisane w zreformowanej konstytucji i liberalnym ustawodawstwie.

Jednak program reform Venizelosa nie nosił znamion rewolucyjnych. Rewizja konstytucji w $1911 \mathrm{r}$. była produktem kompromisu politycznego. Venizelos, kierujący się realizmem politycznym, zrozumiał, że siły konserwatywne i Korona nie utraciły całkowicie społecznego poparcia. Wzmocnienie jedności narodowej stanowiło wtedy warunek skutecznego reagowania na zewnętrzne zagrożenia pochodzące z Turcji i Bułgarii (wojny bałkańskie w 1912 r.). Chociaż większość przepisów nowej konstytucji dalekich

${ }^{60}$ Termin ten pochodzi z tureckiego i oznacza ,wielkich właścicieli ziemskich” w Imperium Osmańskim [przyp. thum.].

${ }^{61}$ Odmiana języka greckiego stworzona na początku XIX w. przez językoznawcę Adamandiosa Koraisa [przyp. thum.]. 
była od radykalizmu (z wyjątkiem art. 17, który utorował drogę do wywłaszczenia dużych majątków wiejskich i rozwiązania kwestii agrarnej) w każdym obszarze, to reforma konstytucji z 1911 r. wniosła decydujący wkład w modernizację instytucjonalną i parlamentarną współczesnej Grecji ${ }^{62}$.

\section{PODSUMOWANIE}

Eleftherios Venizelos osiągnął szczyt popularności w 1915 r. W tym czasie kroczył ścieżką pokojowej rewolucji, tj. drogą rewizji i umiarkowanej reformy podstawowych obszarów życia publicznego kraju. Udało mu się stworzyć warunki do osiągnięcia kompromisu politycznego między ,rewolucjonistami” z jednej strony i starym światem politycznym i Koroną z drugiej strony. Pochodzący z Krety przywódca znalazł się po raz pierwszy w sytuacji bez wyjścia podczas I wojny światowej (w latach 1915-1917), kiedy pod presją kwestii narodowej (Macedonii oraz Azji Mniejszej) zakwestionował trwałość podstaw ustroju politycznego (monarchia) i prerogatyw korony w kluczowych obszarach polityki zagranicznej i w sprawach wojskowych. Konflikt Venizelosa z królem Konstantinosem I, który przez większość Greków (przede wszystkim zwolenników monarchii) uważany był za osobę świętą i nieusuwalną, sprawił, że przeciwko premierowi opowiedziała się większość polityków. Owe „świętokradztwo" stało się główną przyczyną, która doprowadziła o utraty przez niego władzy w wyborach parlamentarnych w 1920 r. Okres historyczny zwany „odrodzeniem Venizelosa” zakończył się nagle 1 listopada 1920 r., a venizelizm nigdy później nie odzyskał popularności, którą cieszył się prawie od dekady (1910-1920). Środek ciężkości na greckiej scenie politycznej przesunął się z postulatów odrodzenia (bez Venizelosa hasło to przepadło całkowicie w nadchodzących dziesięcioleciach) w kierunku dylematu monarchia czy republika. W okresie międzywojennym (1922-1940) prąd modernizacyjny w greckim życiu politycznym uległ przerwaniu i został zastąpiony jałowymi sporami dotyczącymi kształtu ustroju państwa.

\section{BIBLIOGRAFIA}

\section{PIŚMIENNICTWO}

Alastos D., Venizelos: Patriot, Statesman, Revolutionary, Percy Lund Humphries, Londyn 1942. Alivazatos N.K., Instytucje polityczne podczas kryzysu (1922-1974). Aspekty doświadczenia greckiego, thum. W. Stavropoulou, Themelio, Ateny 1983.

Alivazatos N.K., Konstytucja i jej wrogowie w nowożytnej historii greckiej, 1800-2010, Polis, Ateny 2011.

Chester S.B., Life of Venizelos, Constable, London 1921.

Diamantopoulos T.D., Sity polityczne okresu venizelowego, Ant. N. Sakoulas, Ateny 1985.

Diamantopoulos, Thanasis D., 10 dekad i jeszcze jedna dekada podziałów politycznych. Spory polityczne w Grecji w okresie 1910-2017, t. A-C, Epikentro, Saloniki 2017.

${ }^{62} \mathrm{~W}$ przypadku zmian konstytucyjnych z 1911 r. vide N. Alivazatos, Venizelos i instytucjonalna modernizacja kraju..., s. 105-110, 116-117; N. Tsiros, Ustawodawstwo Eleftheriosa Venizelosa w okresie 1911-1920 w ramach reformy polityki $i$ w kontekście społeczno-politycznym epoki, Ateny 2013, s. 69-75. 
Eleftherios Venizelos: The Trials of Statesmanship, red. P.M. Kitromilides, Edinburgh University Press, Edinburgh 2006.

Hering, Gunnar, Partie polityczne w Grecji 1821-1936, thum. T. Paraskevopoulos, t. 2, Fundacja Kulturalna Narodowego Banku (MIET), Ateny 2008.

Leon G.B., Greece and the Great Powers 1914-1917, Institute for Balkan Studies, Saloniki 1974.

Leontaritis G.B., Grecja w pierwszej wojnie światowej 1917-1918, thum. Vassilis Oikonomidis, t. MIET, Ateny 2000.

Mavrogordatos G.T., 1915: podzial narodu, Patakis, Ateny 2015.

Mavrogordatos G.T., Po 1922: przedtużenie podziału, Patakis, Ateny 2017.

Papadakis N.E., Eleftherios Venizelos: The Man, the Leader. Biografia, t. 1-2, Estia, Ateny 2017.

Petalis D.N., Grecja dwóch rządów: Problemy reżimowe, dyplomatyczne i ekonomiczne podziału narodu, Filippotis, Ateny 1988.

Svolopoulos K.D., Eleftherios Venizelos i kryzys polityczny na autonomicznej Krecie 1901-1906, Ikaros, Ateny 2005.

Svolopoulos K.D., Wejście Eleftherios Venizelos w życiu politycznym Grecji i rozwój wewnętrzny od końca roku 1909 r. do 1912 r., [w:] Historia Narodu Greckiego, t. 14, Wydawnictwo Aten, Ateny 1977.

Svolopoulos K.D., Uwagi na temat Eleftheriosa Venizelosa, Kastaniotis, Ateny 2014.

Siros, N., Ustawodawstwo Eleftheriosa Venizelosa w okresie 1911-1920 w ramach reformy polityki $i$ w kontekście społeczno-politycznym epoki, Papazisis, Ateny 2013.

Siros, N., Państwo, władza, system parlamentarny w czasie kryzysu z okresu 1914-1920, Papazisis, Ateny 2013.

Ventiris G., Grecja 1910-1920. Studium historyczne, t. I i II, Pyrsos, Ateny 1931.

Veremis T., Armia w polityce greckiej: od niepodległości do demokracji, Wydawnictwo Courier, Ateny 2000.

Veremis T., Eleftherios Venizelos: Wizjoner wykonalności, Metechmio, Ateny 2017. 